\title{
Adding hepatoprotective plants to beverage water: an alternative to conventional drugs for broiler production
}

\author{
Dieudonné Pascal CHUISSEU DJAMEN ${ }^{1,4^{*}}$, Roland NANKAM CHIMI², \\ Arouna NJAYOU NGAPAGNA ${ }^{2}$, Leonard TEDONG ${ }^{1}$, François-Marie KANMANGNE ${ }^{3}$, \\ Brice Fredy NEMG SIMO ${ }^{4}$, Arnaud KOUAM FONDJO ${ }^{4,5}$, Christelle DOMNGANG ${ }^{1}$, \\ Borris Rosnay GALANI TIETCHEU ${ }^{4,6}$, Ernest DJOKO ${ }^{3}$, Paul MOUNDIPA FEWOU ${ }^{4}$ and \\ Jeanne NGOGANG ${ }^{1}$
}

\author{
${ }^{1}$ Department of Medicine, Medical and Biomedical Sciences, Faculty of Health Sciences, Université des \\ Montagnes, P.O. Box 208, Bangangte, Cameroon. \\ ${ }^{2}$ Department of Agriculture and Veterinary Medicine, Faculty of Health Sciences, Université des Montagnes, \\ P.O. Box 208, Bangangte, Cameroon. \\ ${ }^{3}$ Department of Pharmacy, Faculty of Health Sciences, Université des Montagnes, P.O. Box 208, Bangangte, \\ Cameroon. \\ ${ }^{4}$ Laboratory of Pharmacology and Toxicology, Department of Biochemistry, Faculty of Science, University of \\ Yaoundé I, P.O. Box 812, Yaounde, Cameroon. \\ ${ }^{5}$ Medical Research and Applied Biochemistry Laboratory, Department of Biomedical Sciences, Faculty of \\ Health Sciences, University of Buea, PO Box 63, Buea, Cameroon. \\ ${ }^{6}$ Laboratory of Applied Biochemistry, Department of Biological Sciences, Faculty of Science, University of \\ Ngaoundere, P.O. Box 454, Ngaoundere, Cameroon. \\ *Corresponding author; E-mail: pchuisse@gmail.com, Tel: +237 675070526
}

\begin{abstract}
The present work was to study the effects of Desmoduin adscendens, Khaya grandifoliola, Xylopia phloiodora extracts on growth parameters and selected blood parameters of broilers chickens. A total of 252 broiler chicks were randomly distributed into 4 groups. Chickens of control batch received commercial hepatoprotective (Hepaturyl $1 \mathrm{~g} / \mathrm{l}$ ) and the experimental groups received a formulation based on 3 extracts hepatoprotective plants at a concentration of 200,100 and $50 \mathrm{mg} / \mathrm{kg}$ body weight. The mortality rate of control and experimental groups was $6.3 \%$ and $4.7 \%$ respectively. Average weight of batches at day 48 was, 2.6 for the control, 2.7 for the batch 2, 2.6 batch 3 and $2.5 \mathrm{~kg}$ batch 4 with an average consumption index ranging from 1.6 for the control and 1.7 for the experimental groups. Liver function in broilers was not altered (The values of alanine aminotransferase and aspartate aminotransferase were 5-25 IU/l and 50-350 IU/l respectively). Cholesterolemia, proteinemia and the triglyceridemia increased with the age of the animals $(0.6-4.1 \mathrm{mmol} / \mathrm{l}$; 21-83 g / 1; 0.3- $3.8 \mathrm{~g} / 1$ respectively). The kinetics of the humoral immune response against infectious bursal disease was not influenced. This work has shown that the use of the formulation as hepatoprotective in chick drinking water shows results similar to those of commercial hepatoprotectors.
\end{abstract}

(C) 2020 International Formulae Group. All rights reserved.

Keywords: Broilers, hepatoprotective plants, hepatic functioning, growth performances, immune response. 


\section{INTRODUCTION}

The poultry sector, especially modern poultry, has emerged in recent years as an attractive solution to meet the growing demand for animal protein within the African population (Ayssiwede et al., 2009). Drivers for this growth include: human population growth, greater purchasing power and urbanization. The poultry sector, especially modern poultry, has emerged in recent years as an attractive solution to meet the growing demand for animal protein. Thus, poultry farming, because of its strengths (species with a short cycle, easy to produce, relatively low price, the absence of religious prohibitions against it), occupies a place of choice in the livestock sector in Cameroon (Dupraz et al., 2009). The current scope of poultry farming in Cameroon depends on the particular dynamics of the various farming systems present in the field. Intensive rearing and increased density of poultry on farms are predisposing factors for the emergence of different diseases. Nevertheless, current control methods are essentially based on prophylactic methods. However, to improve the health status of poultry, food additives (antibiotics, probiotics, enzymes, hepatoprotectants and many others) are incorporated into their diet or drinking water ( Tayeb et al., 2009; Seal et al., 2013; Tubéry et al., 2015; Roger \& Ducrot, 2017)

The use of antibiotics as growth promoters has been banned in recent decade because of development of antibiotic resistant bacteria and their residue in animal products and the potential harmful effects on human health. Therefore, there is increasing interests to find alternatives for antibiotics in recent years. Pro and prebiotics, enzymes, acidifiers, phytogenic and herbal products have been investigated as alternatives to antibiotic in animal feed (Yang et al., 2009). Many beneficial effects for bioactive herbal derivatives and essential oils (EO's) has been reported including increase in digestive enzymes secretion and activities, improving gut health by selectively growth stimulating effects on useful bacterial species and inhibition of pathogens and improving immune system status (Jang et al., 2007; Bolukbasi et al., 2008; Rahimi et al., 2011;
Kouam et al., 2017). Therefore, EO of herbs could be considered as a potential replacement for antibiotic growth promoters. Therefore, the traditional pharmacopoeia, advocates the use of several plant species with therapeutic properties, which may have effects on the digestion and immune system of broilers. These plant-derived substances have the advantage of good liver function, an immunomodulatory effect, the minimization of some of the side effects of modern drugs, and more importantly the reduction of the cost of therapy (Taheri et al., 2005; Namvari et al., 2011).

Thus, the aqueous extract of the bark of Khaya grandifiolia has shown a favorable effect on the reduction of blood cholesterol and glucose levels in the rat (Stephen et al., 2009). Its extract on the other hand, demonstrated significant activity $(p<0.05)$ in the activities of plasma AST, ALT and a decrease in plasma ALP, hepatic AST and 'ALT compared to control after 1 week of administration in rats (Bumah \& Agbedahunsi, 2010). The methylene chloride / methanol mixture extract of the bark exhibited hepatoprotective and immunomodulatory potentialities, the methylene chloride / methanol fraction from the crude extract showed in vitro hepatoprotective activity (Njayou et al., 2004; Owona et al., 2013). The antioxidant activity and hepatoprotective properties of this plant have also been demonstrated (Njayou et al., 2013). Also, Xylopia phloiodora leaves and stem bark extracts showed hepatoprotective activities at doses equivalent to $2.5 \mathrm{~g}$ plant $/ \mathrm{kg}$, since serum levels of ALAT and ASAT in the extract treated rats were, according to the investigators, significantly weak compared to control $\mathrm{CCl}_{4}$-injured rats (Moundipa et al., 2007). Moreover, Desmoduin adscendens enjoys an excellent reputation and is used for various purposes by naturopaths and other traditional practitioners because of its hepatoprotective and immunomodulatory role in both human medicine and animal medicine (Magielse et al., 2013; Tubéry et al., 2015; Chuisseu et al., 2020).

These beneficial effects observed in previous studies can be an asset to boost 
production in farms, hence the justification of this study. The objective of this study was to determine the effects of the inclusion of a hepatoprotective phyto-formulation in drinking water, on the production performance of broiler chickens.

\section{MATERIALS AND METHODS Materials}

With regard to the animal material, the study was carried out on 252 one-day-old Cobb 500 broiler chicks from the AGROCAM hatchery in Bafoussam. The plant material was a basic formulation of 3 hepatoprotective plants (Desmoduin adscendens, Khaya grandifoliola and Xylopia phloiodora) that have been prepared at the Laboratory of Galenic Pharmacy of the Higher Institute of Health Sciences of Université des Montagnes.

The botanical identification of the plants was done at the Cameroon National Herbarium, where voucher specimens were kept under the reference numbers 6425-RFCAM for $D$. adscendens, 23434 YA for $K$. grandifoliola and 10259/SRF CAM for $X$. phloiodora.

\section{Methods \\ Sanitary prophylaxis}

The building was emptied and cleaned. The disinfection was carried out with $\mathrm{TH}_{4}$ a commercial product based on quaternary ammoniums. A crawl space of 15 days has been respected. Before the arrival of the chicks for the experiment, the litter was distributed on the ground and disinfected with the disinfectants mentioned above.

\section{Chickens and experimental treatments}

The experiment started with 252 chicks (Cobb 500), in a completely random test with 4 treatments and 63 chickens per treatment. All animals received a standard diet for broilers (Table 1).

However, batch 1 chickens received a commercial hepatoprotectant (Hepaturyl, the active ingredient of this product is sorbitol) administered at $1 \mathrm{~g} / \mathrm{l}$ according to the manufacturer's dosage, while those in the experimental groups received the formulation based on 3 hepatoprotective plant extracts at $50, \quad 100$ and $200 \mathrm{mg} / \mathrm{kg}$ body weight respectively for group 2, 3 and 4, respectively, during days 2-5, 14-18 and 35-38 in drinking water.

\section{Clinical and zootechnical follow-up}

The vaccination program which included vaccination against infectious bronchitis virus, Newcastle disease and Gumboro disease, was implemented by the hatchery. The animals were observed daily. Clinical signs were noted and autopsies performed on dead animals. For weight monitoring, ten chickens were chosen by random draw and weighed each weekend until the 7 th week. Data on zootechnical parameters were recorded and calculated. For each of the Batchs, the mortality rate (MR) and the consumption index $(\mathrm{CI})$ were calculated and converted into a performance index (PI).

\section{Biochemical and immunological parameters}

During the experiment, 10 subjects from each batch were randomly selected for blood sampling. This operation was carried out on D7, D14, D21, D28, D35, D42 and D48. Three (3) to five (5) $\mathrm{ml}$ of blood were collected from the right wing vein of the subjects, in dry hemolysis tubes, allowed to stand for $30 \mathrm{~min}$, then transported to the laboratory and centrifuged at $3000 \mathrm{rpm}$ for 10 min. The fresh serum obtained was recovered using a micropipette and divided into aliquots that were stored in the freezer at $-20{ }^{\circ} \mathrm{C}$ for biochemical and immunological assays. The levels of total cholesterol, triglycerides, total proteins and transaminase activity (ALAT and ASAT) were determined. The anti-Gumboro antibody assay was performed by indirect ELISA. The principles of the analytical methods and the references of the techniques used for biochemical and immunological analyzes are summarized in Table 2.

\section{Statistical analysis}

The statistical analysis was performed using $\mathrm{R}$ version 5.0 software to calculate the mean \pm Standard Error of the Mean of the different variables of the study. The comparison of the means of the variables between the experimental groups and the control group was performed by the Student's t-test and $p<0.05$ was considered statistically significant. 
Table 1: Composition of the standard diet for broilers, distributed by the company Sociéte des Provenderies du Cameroun.

\begin{tabular}{lccc}
\hline $\begin{array}{l}\text { Determined } \\
\text { components }(\%)\end{array}$ & $\begin{array}{c}\text { Start-up } \\
(\mathbf{1 - 2 1} \text { days })\end{array}$ & $\begin{array}{c}\text { Growth } \\
\mathbf{( 2 1 - 3 5} \text { days })\end{array}$ & $\begin{array}{c}\text { Finish } \\
\mathbf{( 3 5 - 4 8 ~ d a y s )}\end{array}$ \\
\hline Raw protein & Min 22 & Min 20 & Min 19.5 \\
\hline Fat & Min 6 & Min 6 & Min 8 \\
\hline Humidity & Max 12 & Max 12 & Max12 \\
\hline Crude fiber & Max 3.5 & Max 3.6 & Max 4 \\
\hline Ashes & Max 5 & Max 5 & \\
\hline
\end{tabular}

Min= Minimum ; Max= Maximum

Table 2: Analytical methods.

\begin{tabular}{lllc}
\hline \multicolumn{2}{c}{ Parameter } & \multicolumn{2}{c}{ Analysis Method } \\
\hline \multirow{2}{*}{ Organic elements } & Total protein & Colorimetric, biuret & Inmesco Kit \\
\cline { 2 - 4 } & Total Cholesterol & Enzymatic, Colorimetric & Inmesco Kit \\
\cline { 2 - 4 } & Triglycerides & Enzymatic, Colorimetric & Inmesco Kit \\
\hline \multirow{2}{*}{ Enzymes } & ALAT & Kinetics.IFCC, UV-37 ${ }^{\circ} \mathrm{C}$ & Inmesco Kit \\
\cline { 2 - 4 } & ASAT & Kinetics.IFCC, UV-37 ${ }^{\circ} \mathrm{C}$ & Inmesco Kit \\
\hline Immunology & $\begin{array}{l}\text { Antibody titration against } \\
\text { Gumboro disease }\end{array}$ & Indirect ELISA & BioChek" - ref : CK113 \\
\hline $\begin{array}{l}\text { UV= Ultraviolet, IFCC= International Federation of Clinical Chemestry and Laboratory } \\
\text { Aminotransferase, ASAT= Aspartate Aminotransferase, IBD=Infectious bursal disease. }\end{array}$ &
\end{tabular}

\section{RESULTS}

\section{Zootechnical parameters}

The MR in the four batches, for the total period of the breeding ranged from 1.6 to $9.5 \%$ with an average of $5.1 \%$. It shows that the highest MR was recorded in lot 4 , which received the highest dose of the formulation. The average weight of batches at day 48 varies from 2.5 to $2.7 \mathrm{~kg}$ with an average of $2.6 \mathrm{~kg}$ for the whole band. During the seven weeks we did not observe a significant difference between the weights of the subjects of the experimental batch and those of the control batch.
We note, however, a non-significant improvement in the weights of the chickens in weeks 2 and 3 in weeks 6 and 7. The overall CI was 1.71 , with values ranging from 1.69 to 1.75. We generally notice that there is no significant difference in daily food consumption in different batches. The incorporation of hepatoprotective plant extracts into the drinking water improves the feed intake of birds from the third week to the end of the experiment. The PI has been calculated for all Batches and ranges from 281.70 to 321.22 . No significant difference in the ponderal monitoring of the poultry of the 
different lots. The results obtained in each batch are shown in Table 3.

\section{Biochemical analyses}

Serum alanine aminotransferase (ALAT) rate

ALAT is an enzyme whose determination of serum UI/l allows evaluating and monitoring the functioning of the liver (Samali et al., 2012). Normal values are around 5 to $25 \mathrm{IU} / 1$ in chicken. Figure 1 show the serum alanine aminotransferase rate obtained in the different batches at regular time intervals. The comparison of the means \pm standard obtained between the four batches shows non-statistically significant differences $(\mathrm{p}=0.406)$. We noted that ALAT activity was high at W3, W4 and W6 which corresponds to periods of dietary change. This variation remains normal around 5-25 IU/1

\section{Serum aspartate aminotransferase (ASAT) rate}

ASAT is an enzyme whose serum rate is used to assess the state of the liver but also the functioning of the heart. Its usual normal values are between 50-350 IU/l in the chicken. Figure 2 show the serum aspartate aminotransferase rate obtained in the different batches at regular time intervals. The values obtained and compared with each other do not show statistically significant differences $(\mathrm{p}=0.6005)$. ASAT activity was high at $\mathrm{W} 2$, W4 and W6, which corresponds to periods of dietary change. This variation remains normal around 50-350 IU/1.

\section{Total cholesterol}

Figure 3 show the variation in cholesterol rate obtained in the different batches at regular time intervals. Normal values are around 0.6- $4.1 \mathrm{mmol} / \mathrm{l}$. The cholesterolemia observed in our study increases with the age of the animals. However, from one group to another for the same period, no significant differences are noted $(\mathrm{p}=0.9324)$.

\section{Triglyceride rate}

Normal values are around $0.3-3.8 \mathrm{~g} / 1$. Figure 4 shows the variation in triglyceride rate of animals from different groups during the experiment. Triglyceridemia observed in our study increased with age of animals. However, we noted a decrease in $\mathrm{W} 5$ triglyceride levels in the 4 lots followed by an increase to W 7 (Figure 4). However, from one group to another and for the same period, no significant differences are noted $(\mathrm{p}=0.4323)$ in Figure 4.

\section{Rate proteins}

Proteins are the main component of cells, accounting for more than $50 \%$ of their dry weight. Normal values are around 21-83 $\mathrm{g} / \mathrm{l}$. The proteinemia observed in our study increases with the age of the animals (Figure 5). However, from one group to another for the same period, no significant differences $(\mathrm{p}=0.8611)$ are noted in Figure 5.

\section{Immunological result}

Like natural infection, vaccination induces a humoral and cellular immune response. The protection provided by current vaccines relies mainly on the induction of neutralizing antibodies (antibodies capable of neutralizing pathogens or facilitating their phagocytosis and elimination). The nature and intensity of the response will vary depending on two parameters: the type of vaccine administered (live or inactivated) and host factors. Figure 6 shows the kinetics of the antibodies against infectious bursal virus of the different groups throughout the experiment. The statistical treatment did not show a significant difference between the batches at W1 until S7 $(\mathrm{p}=0.2258)$. On the other hand, at W4, we notice an improvement in the antibody titer of lot 2 compared with the control group. The first 3 weeks are marked by a decrease in the titer of the antibodies in the 4 batches, then an exponential growth of the antibody level up to the W4 for the lot 2 and the W5 for the batch 1,3 and 4. A fall in antibody titer at week 6 was noted (Figure 6). 
Table 3: Zootechnical parameters of batches.

\begin{tabular}{clccccc}
\hline Batches & \multicolumn{1}{c}{$\begin{array}{c}\text { Hepatoprotective } \\
\text { treatment }\end{array}$} & Dosage & MR $(\%)$ & CI & ALW & PI \\
\hline $\mathbf{1}$ & Hepaturyl & $1 \mathrm{~g} / \mathrm{l}$ & 6.3 & 1.69 & 2.65 & 305.80 \\
\hline $\mathbf{2}$ & Phyto-formulation & $50 \mathrm{mg} / \mathrm{kg}$ & 3.2 & 1.72 & 2.74 & 321.22 \\
\hline $\mathbf{3}$ & Phyto-formulation & $100 \mathrm{mg} / \mathrm{kg}$ & 1.6 & 1.75 & 2.68 & 314.04 \\
\hline $\mathbf{4}$ & Phyto-formulation & $200 \mathrm{mg} / \mathrm{kg}$ & 9.5 & 1.70 & 2.54 & 281.70 \\
\hline ALW $=$ Average live weight; CI = Consumption Index; MR= Mortality Rate; PI = performance index. & &
\end{tabular}

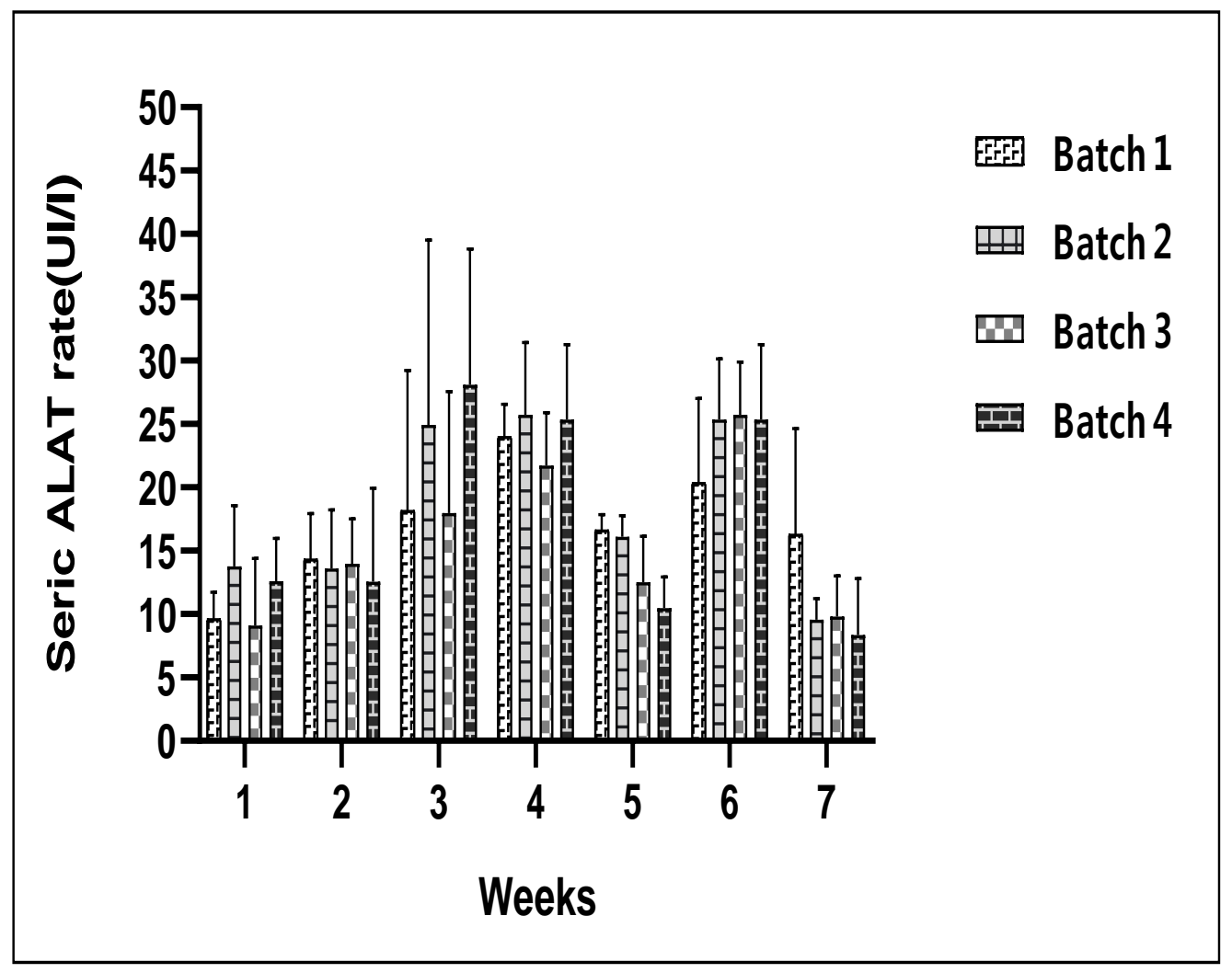

Figure 1: Variation in serum ALAT rate during chicks rearing. Results are represented as means \pm standard deviation. No Significant difference $(\mathrm{p}=0.406)$ compared to control group. Batch $1=$ control, Batch 2, 3, 4= experimental groups 


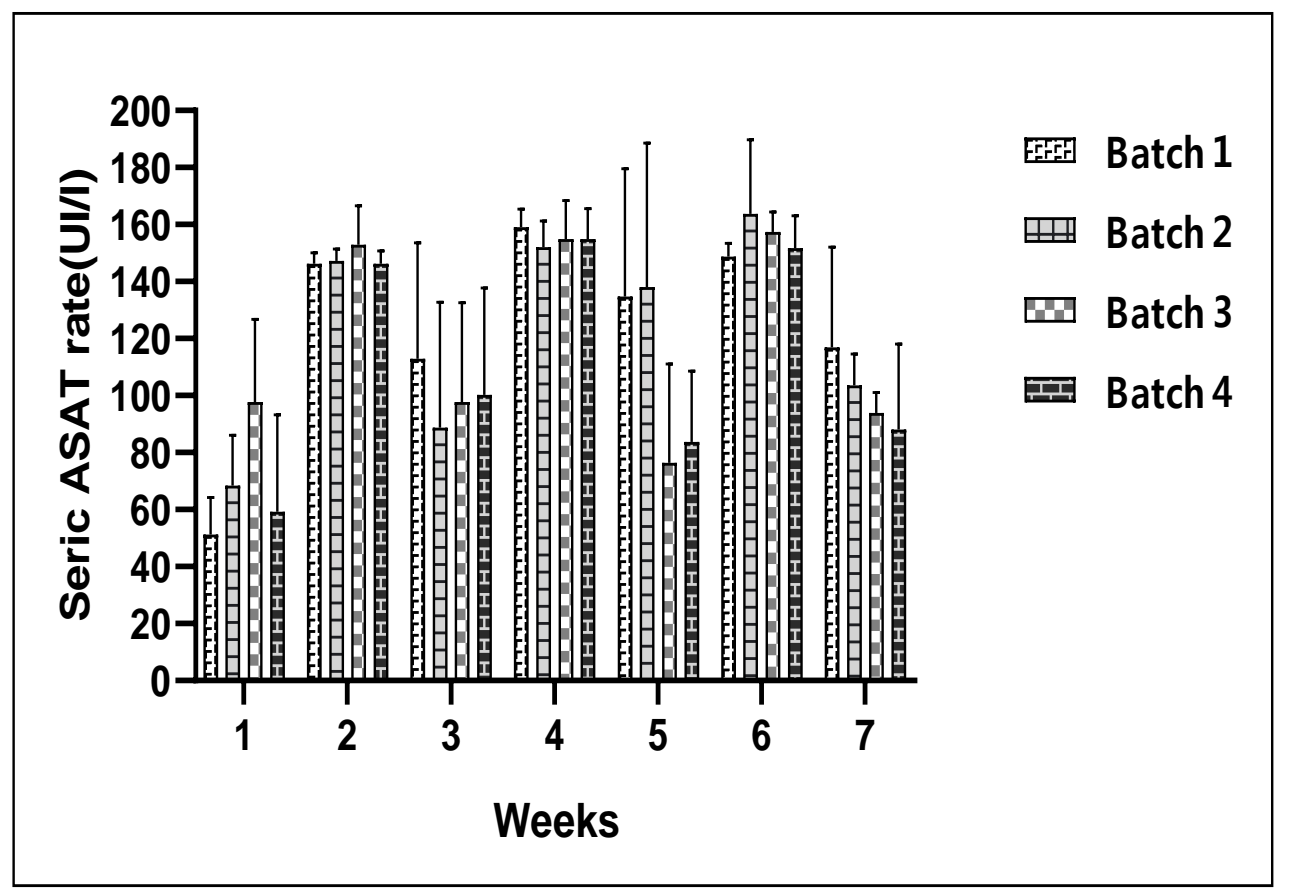

Figure 2: Variation in serum aspartate aminotransferase rate during chick rearing. Results are represented as means \pm standard deviation. No Significant difference $(\mathrm{p}=0.6005)$ compared to control group. Batch 1 $=$ control, Batch 2, 3, 4= experimental groups

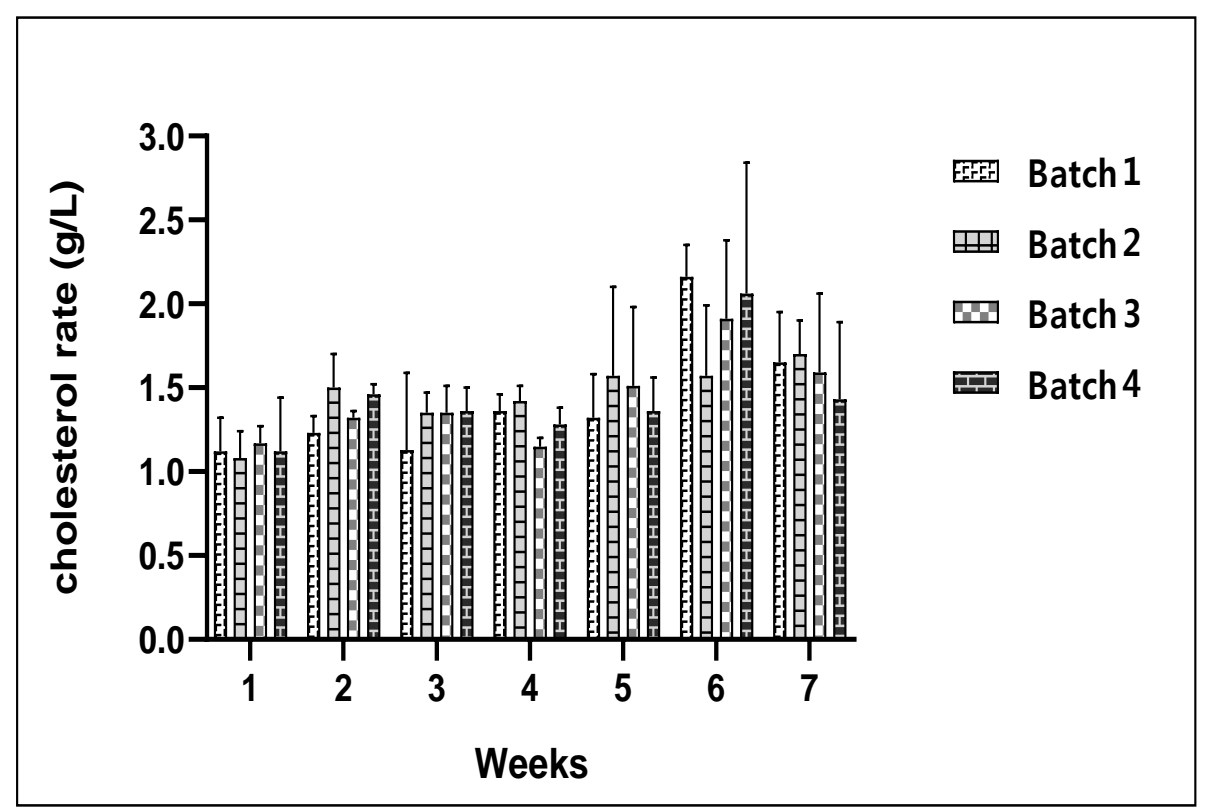

Figure 3: Variation in total cholesterol rate during chick rearing. Results are represented as means \pm standard deviation. No Significant difference ( $\mathrm{p}=0.9324)$ compared to control group. Batch $1=$ control, Batch 2, 3, 4= experimental groups. 


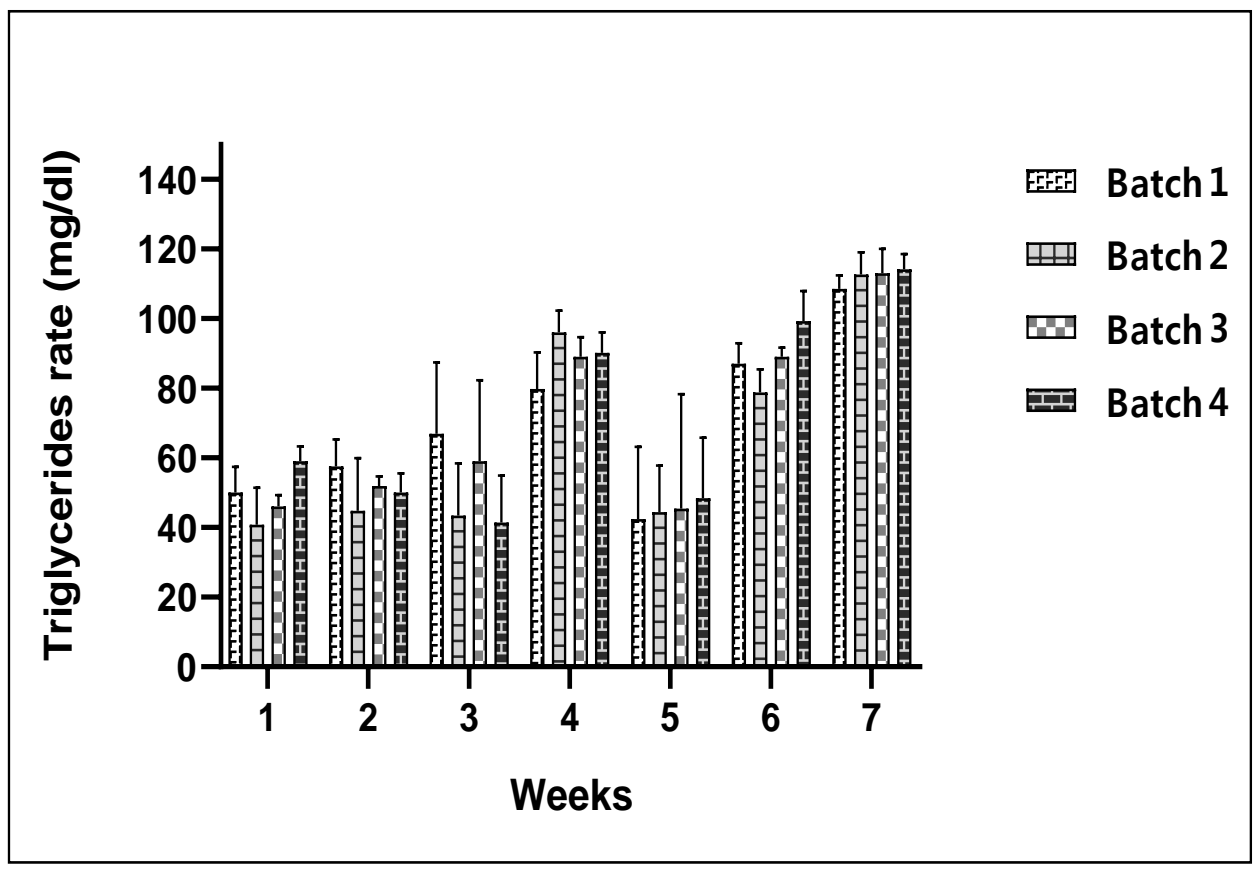

Figure 4: Variation in serum triglyceride levels during chick rearing. Results are represented as means \pm standard deviation. No Significant difference $(\mathrm{p}=0.4323)$ compared to control group. Batch $1=$ control, Batch 2, 3, 4= experimental groups.

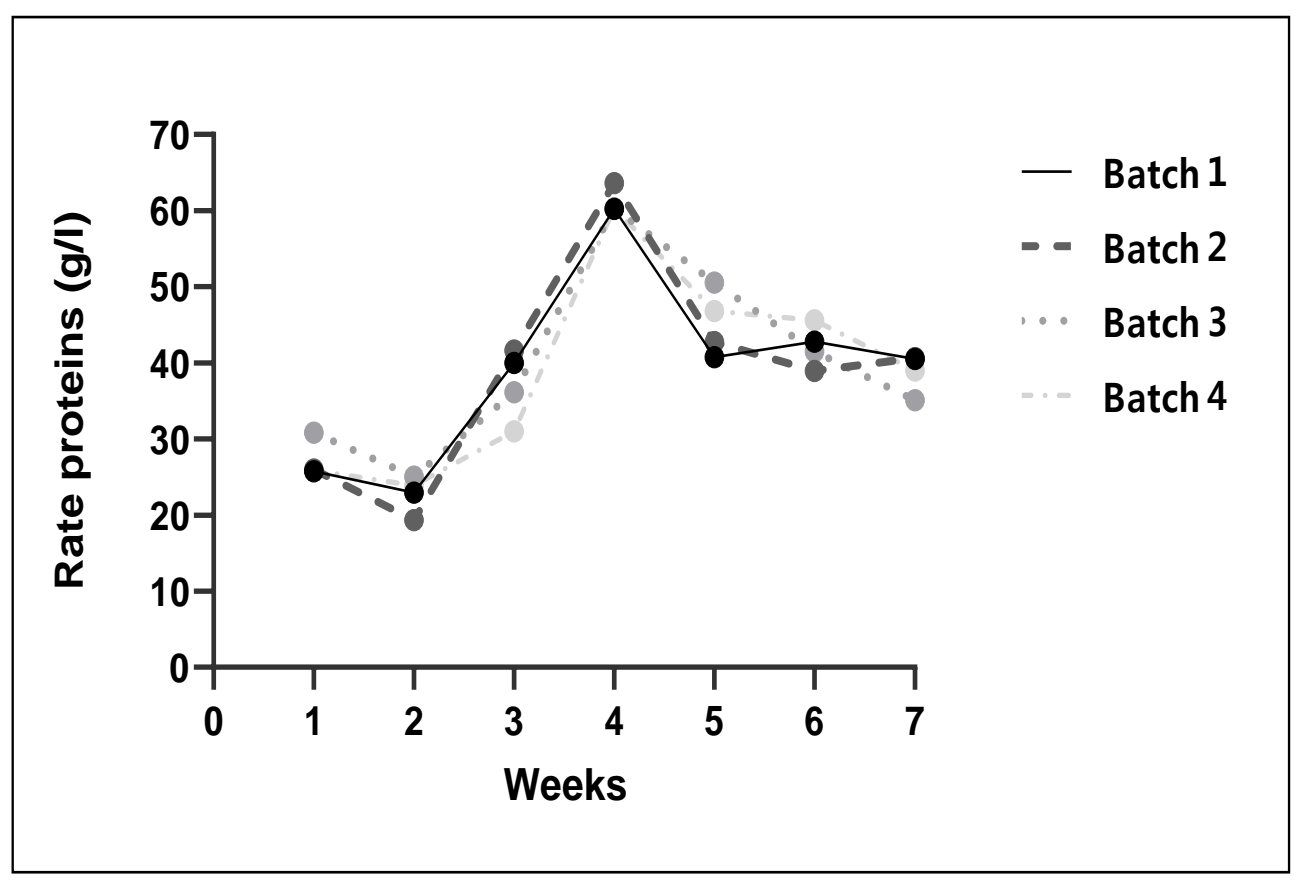

Figure 5: Variation in serum proteins levels rate during chick rearing. Results are represented as means \pm standard deviation. No Significant difference $(\mathrm{p}=0.8611)$ compared to control group. Batch $1=$ control, Batch 2, 3, 4= experimental groups. 


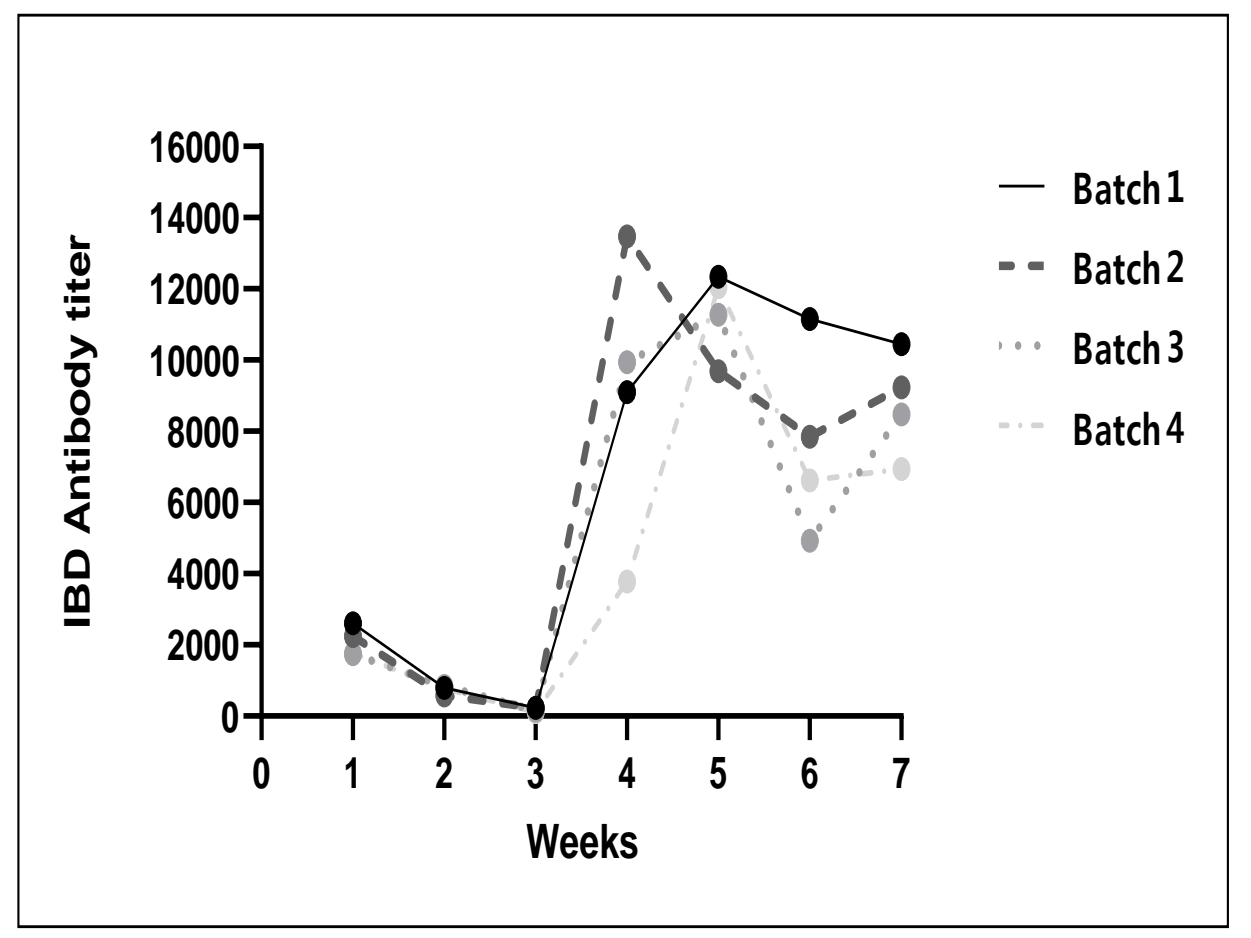

Figure 6: Variation of antibody titer against infectious bursal disease during chick rearing. Results are represented as means \pm standard deviation. No Significant difference $(\mathrm{p}=0.2258)$ compared to control group. Batch $1=$ control, Batch 2, 3, 4 = experimental groups.

\section{DISCUSSION}

The MR recorded during the experiment was $5.1 \%$. We found that it was higher in batch $4(9.5 \%)$. However, it was low in batch $2(3.2 \%)$ and $3(1.6 \%)$ as compared to control batch. The antioxidant and hepatoprotective properties of the formulation may have given some resistance to the chicks of these experimental batches (Feher \& Lengyel, 2011). It's during the start-up phase that the MR was highest for the four lots. This can be explained by the stress during transportation and handling during the installation of the chicks (Simonin, 2018). The formulation has no adverse effect on the zootechnical performance of subjects in experimental batches compared to the control lot. In poultry, the use of hepatoprotective agents has beneficial effects on food consumption and feed efficiency. These results are similar to those obtained by Teguia et al. (2002) who showed that the dry leaves of Desmodium $s p$ resulted in a drop in the consumption index of $6 \%$ in the starter food and $10 \%$ in the growth food (Teguia et al. 2007).

The results of the activity of ALAT and ASAT obtained indicated a normal activity in all the batches, which highlights the hepatoprotective activity of these plant extracts. ALAT is the most specific transaminase in the liver because of its hepatic and muscular localization, whereas ASAT is more specific in the kidneys, heart, skeletal muscles and liver. In contrast, ASAT activity increased with the age of the subjects in our study. This could have been due to an increase in metabolic activity of the liver and muscle development. The difference between individuals in each lot could be due to agerelated physiological changes (Slominski, 2011; Kouam et al., 2017).

An increase in cholesterol levels in each of the experimental and control batches as a function of age was observed. According to the studies of Grizzle et al. (2009), charcoal 
does not reduce cholesterol levels during all rearing phases (Grizzle et al., 2009). The results obtained show similar blood triglyceride values in the four batches $(p>0.05)$. These show that hepatoprotective plants have no adverse effect on the blood triglyceride content. The lipid content of blood represented by triglycerides and cholesterol is identical in the experimental lot and control lot. This can be because the studied hepatoprotective plant extract and commercial hepatoprotective both have a cholesterollowering property that may be due to inhibition of hepatic cholesterol synthesis and their ability to deconjugate bile salts (Mamoudou et al., 2014). The protidemia observed during our study increases with the age of the animals. However, from one group to another and for the same period, no significant difference is noted. These show that hepatoprotective plants have no adverse effect on the protein content of the blood.

Like natural infections, vaccination induces a humoral and cellular immune response. The protection provided by current vaccines relies mainly on the induction of neutralizing antibodies (antibodies capable of neutralizing pathogens or facilitating their phagocytosis and elimination). The nature and intensity of the response will vary depending on two parameters: the type of vaccine administered (live or inactivated) and host factors (Dao et al., 2001). However, the statistical analysis did not show a significant difference between the antibody titers of the $\mathrm{W} 1$ to $\mathrm{W} 7$ batches $(\mathrm{p}>0.05)$. This can be justified by the fact that the injected vaccine strain, gaining the Fabricius stock exchange, multiplies and prevents the penetration of wild viruses by an interference phenomenon. This multiplication did not significantly increase the weight of the Fabricius bursa in our study. The primary vaccination was carried out on D1, by nebulization, at the same time as vaccination against Newcastle disease and infectious bronchitis. The recall took place on D7 and the beginning of the samples on D7. This is why the antibody titers are not very high at this time. In addition, the persistence of antibodies of maternal origin probably limits the production of vaccine antibodies (Dao et al., 2001). A W4; and W5, 14 days and 28 days after the booster, the titers of the vaccine antibodies are much higher. Thus, Taheri et al., (2005) and Aghdam et al. (2011) respectively demonstrate the effect of propolis oil extract and the effect of propolis alcohol extract on the immune system of the chicken (Namvari et al., 2011; Taheri et al., 2005). The same is true for Dao et al. (2001) when studying a vaccination program in Viet Nam against Newcastle disease, Gumboro disease, and avian infectious bronchitis (Dao et al., 2001).

However, the study conducted by Cường \& Bích, (2018) confirms the independence and non-interaction of the vaccine against Gumboro disease from that directed against Newcastle disease and infectious bronchitis (Cường \& Bích, 2018).

\section{Conclusion}

Medicinal plants are widely used in Africa and developing countries. They are nowadays natural substances used in various fields. It is therefore vital to look for high efficiency, low toxicity and low cost plants. In order to reduce the cost of production, we proposed to determine the effect of the inclusion of a hepatoprotective phytoformulation in drinking water on broiler production performance. In general, the results have demonstrated that the use of the formulation as a hepatoprotectant in chicks' drinking water shows similar results to those of commercial hepatoprotectants. These hepatoprotective plants (Desmodium adscendens, Xylopia phloiodora and Khaya grandifoliola) in combination therefore do not present at this stage of experimentation significant differences in the parameters studied.

\section{COMPETING INTERESTS}

The authors declare that they have no competing interests.

\section{AUTHORS' CONTRIBUTIONS}

PDDC, ANN, LT, FMK and JN designed the experiment; PDDC, RCN, ANN, 
BFNS, AFK and ED carried out the experiments; PDDC, RCN, CD, BRTG wrote the manuscript; PDCD, RCN and CD analyzed data; PFM and JN supervised the work. All authors revised the manuscript critically for important intellectual content, and approved to be published.

\section{ACKNOWLEDGEMENTS}

We thank Pr Chicgoua Noubactep, from Universität Göttingen (Germany) and Mrs. Dremoh Ndeloa from the University of Dschang (Cameroon) for their contributions to the formatting of this document. Authors are thankful the Université des Montagnes which financed this work through the research grant $\mathrm{N}^{\circ}$ UdM-BUR-CPR-2014/006

\section{REFERENCES}

Ayssiwede SB, Azebaze SP, Missohou A. 2009. Effets de la substitution du tourteau d' arachide par le tourteau de neem (Azadirachta indica) sur les performances zootechniques du poulet de chair. RASPA. E.I.S.M.V. de Dakar, 7(S): 25-32.

DOI: https://www.academia.edu/4825662/A_A _R_R_TICLE_TICLE_ORIGINAL_ORI GINAL

Bolukbasi SC, Erhan MK, Erzurum. 2008. Effect of dietary thyme (Thymus vulgaris) on laying hens performance and Escherichia coli (E. coli) concentration in feces. Turkish Nat. AGRIS Center. 1(2): DOI: https://agris.fao.org/agrissearch/search.do?recordID=TR20070000 95

Bumah V, Agbedahunsi J. 2010. Toxicological studies of the stem bark extract of Khaya grandifoliola in rats. Niger J. Nat. Prod. Med., 13(1): 46-52. DOI: 10.4314/njnpm.v13i1.61601

Chuisseu PDD, Galani BRT, Younang NCK, Kouam AF, Simo BFN, Tchana AN, Seron K, Dubuisson J, Tiegs G, Kouamouo J, Moundipa PF. 2020. Aqueous extracts of Desmodium adscendens (Fabaceae) possess in vitro antioxidant properties and protect hepatocytes from Carbone tetrachloride- induced injury and Hepatitis C Virus infection. Invest. Med. Chem. Pharmacol. 3(1):36; Doi: https://dx.doi.org/10.31183/imcp.2020.00 036

Cường NP, Bích TN. 2018. Caractéristiques épidémiologiques de la maladie de gumboro chez les poulets du delta du Mékong. Can Tho University. J. of Sc., 54(4), $40 . \quad$ DOI: https://doi.org/10.22144/ctu.jvn.2018.067

Dao BT, Tripodi A, Carles M, Bodin G. 2001. Maladie de Newcastle, Maladie de Gumboro et bronchite infectieuse aviaire au Viet Nam: Intérêt médical et économique d'un programme de vaccination mis en place dans la région d'Ho Chi Minh Ville. Rev. Med. Vet., 152(3): 239-246. DOI: https://www.revmedvet.com/2001/RMV1 52_239_246.pdf

Dupraz CL, Awono C, Vermersch D. 2009. Impact des politiques commerciales sur le marché du poulet au Cameroun. Intérêts et limites d'un modèle d'équilibre partielImpact of trade policies in Cameroon chicken market. Interest and limits of a partial equilibrium model. Éco. Ru., 313-314: 67-84. DOI: https://doi.org/10.4000/economierurale.2 395

Feher J, Lengyel G. 2011. Silymarin in the Prevention and Treatment of Liver Diseases and Primary Liver Cancer. Curr. Pharm. Biotechno., 13(1): 210217.

DOI: https://doi.org/10.2174/13892011279886 8818

Grizzle J, Hadley TL, Rotstein DS, Perrin SL, Gerhardt LE, Beam JD, Saxton AM, Jones MP, Daniel GB. 2009. Effects of Dietary Milk Thistle on Blood Parameters, Liver Pathology, and Hepatobiliary Scintigraphy in White Carneaux Pigeons (Columba livia) Challenged With B 1 Aflatoxin. J. Avian. Med. Surg., 23(2): 114-124. DOI: https://doi.org/10.1647/2008-020.1

Jang IS, Ko YH, Kang SY, Lee CY. 2007. Effect of a commercial essential oil on 
growth performance, digestive enzyme activity and intestinal microflora population in broiler chickens. Anim. Feed Sci. Tech., 134(3-4): 304-315. DOI:https://doi.org/10.1016/j.anifeedsci. 2006.06.009

Kouam AF, Yuan F, Njayou FN, He H., Tsayem, RF, Oladejo BO, Song F, Moundipa PF, Gao GF. 2017. Induction of Mkp-1 and nuclear translocation of Nrf2 by limonoids from Khaya grandifoliola C.DC protect L-02 hepatocytes against acetaminopheninduced hepatotoxicity. Front. Pharmacol., 8(SEP): 1-18. DOI: https://doi.org/10.3389/fphar.2017.00653

Magielse J, Arcoraci T, Breynaert A, Dooren IV, Kanyanga C, Fransen E, Hoof VV, Vlietinck A, Apers S, Pieters L, Hermans N. 2013. Antihepatotoxic activity of a quantified Desmodium adscendens decoction and D-pinitol against chemically-induced liver damage in rats. J. Ethnopharmacol., 146(1): 250-256. DOI:https://doi.org/10.1016/j.jep.2012.1 2.039

Mamoudou B, Moussa O, Seydou S, GUISSOU IP. 2014. Intérêt thérapeutique de la spiruline chez l'homme: revue général. Int. J. Biol. Chem. Sci., 8(6): 2740-2749. DOI: http://ajol.info/index.php/ijbcs

Moundipa PF, Ngouéla S, Tchamba GA, Njayou NF, Chuisseu, PD, Zéléfack F, Tsamo E. 2007. Antihepatotoxic activity of Xylopia phloiodora extracts on some experimental models of liver injury in rats. Int. J. Pharmacol., 3(1): 74-79. DOI:https://doi.org/10.3923/ijp.2007.74. 79

Namvari M, Nourollahi H, Tili AS. 2011. Effect of Alcoholic Extract Propolis on Immune System in Broiler Chickens. Semantic Scholar. DOI: https://doi.org/https://www.semanticscho lar.org/paper/Effect-of-Alcoholic-

Extract-Propolis-on-Immune-in-

Namvari-

Nourollahi/7775ba6839208be4d045a2f5a f1e69e3bdf984e4
Njayou F, Moundipa P, Tchana AN, Tchouanguep F. 2004. Antihepatotoxic potential of three Bamun folk medicinal plants. J. Acad. Mark. Sci., 4: 325-330. DOI:https://doi.org/https://www.ajol.info /index.php/jcas/article/download/17672/1 6813

Njayou FN, Aboudi EC, Tandjang MK, Tchana A, Ngadjui BT, Moundipa PF. 2013. Hepatoprotective and antioxidant activities of stem bark extract of Khaya grandifoliola (Welw) CDC and Entada africana Guill. et Perr. J. Nat. Prod., 6: 73-80.

DOI: https://www.researchgate.net/publication/ 235988965

Owona BA, Njayou NF, Laufer SA, Schluesener HJ, Moundipa PF. 2013. Entada africana fraction $\mathrm{CH} 2 \mathrm{Cl} 2 / \mathrm{MEOH}$ $5 \%$ inhibits inducible nitric oxide synthase and pro-inflammatory cytokines gene expression induced by lipopolysaccharide in microglia. BMC Complem Altern M., 13(1), 1-7. DOI: https://doi.org/10.1186/1472-688213-254

Rahimi S, Teymouri Zadeh Z, Karimi Torshizi MA, Omidbaigi R, Rokni H. 2011. Effect of the three herbal extracts on growth performance, immune system, blood factors and intestinal selected bacterial population in broiler chickens. J. Agr. Sci. Tech-Iran., 13(4), 527-539. DOI: https://doi.org/https://jast.modares.ac.ir/a rticle-23-5732-en.pdf

Roger F, Ducrot C. 2017. Antibiotiques en agriculture: réduire leur usage tout en limitant les risques sanitaires et socioéconomiques au Sud. In Sud. Cirad, Monpelier, Perspective 39: (1-4). DOI: https://doi.org/10.18167/agritrop/00041

Samali A, Tarfa FD, Odeniran OA, Onanuga CE, Adzu B. 2012. Evaluation of efficacious activities of aqueous extract of Phyllanthus niruriagainst acetaminophen-induced hepatitis in rats. Int. J. Biol. Chem. Sci. 6(3): 920-930. DOI:http://dx.doi.org/10.4314/ijbcs.v6i3. 1

Seal BS, Lillehoj HS, Donovan DM, Gay CG. 
2013. Alternatives to antibiotics: a symposium on the challenges and solutions for animal production. Conference of Research Workers in Animal Diseases. Anim. Health Res. Rev., 14(1): 78-87. DOI: https://doi.org/10.1017/S1466252313000 030

Simonin D. 2018. Guide des bonnes pratiques pour le transport des volailles. DOI: http://animaltransportguides.eu/wpcontent/uploads/2017/03/FR-Guides-toGood-practices-for-the-Transport-ofPoultry.pdf

Slominski BA. 2011. Recent advances in research on enzymes for poultry diets. Poult. Sci. J., 90(9): 2013-2023. DOI: https://doi.org/10.3382/ps.2011-01372

Stephen UA, Abiodun F, Osahon O, Ewaen E. 2009. Phytochemical analysis and antibacterial activity of Khaya grandifoliola stem bark. Res. J. Biol. Sci., 9(1): $63-67 . \quad$ DOI: https://doi.org/10.3923/jbs.2009.63.67

Taheri HR, Rahmani HR, Pourreza J. 2005. Humoral immunity of broilers is affected by oil extracted propolis (OEP) in the diet. Int. J. Poult. Sci., 4(6): 414-417. DOI:https://doi.org/10.3923/ijps.2005.41 4.417

Tayeb I, Djamel B, Essaid L, Noureddine K. 2009. Activite Probiotique De Lactobacillus Plantarum: Etude Realisee
Chez Le Poulet De Chair Isa 15. Huitièmes Journées de La Recherche Avicole, St Malo. 312-315. DOI: https://doi.org/http://journees-de-larecherche-foiegras.org/Download.php?telecharger=ALI MJRA2009.pdf

Teguia A, Awah-Ndukum J, Puene C. 2007. Effects of replacing maize with dried leaves of desmodium spp on the growth performance of broiler chickens. Bull. Anim. Health Prod. Afr., 50(2): 106-114. DOI:https://doi.org/10.4314/bahpa.v50i2. 32748

Tubéry P, Ragot J, Lagarde P, Authier-derivau D, Pidoux M, Rasolohery C, Bourdy G. 2015. Desmodium adscendens de l'usage traditionnel camerounais contre les hépatites aux applications contemporaines en europe résumé. Ethnopharmacologia, 53: 71-83. DOI: https://doi.org/https://www.crpphyto.com/img/cms/Desmodium\%20def \%20Ethnopharm\%2053.pdf

Yang Y, Iji PA, Choct M. 2009. Dietary modulation of gut microflora in broiler chickens: a review of the role of six kinds of alternatives to in-feed antibiotics. World Poultry Sci. J., 65(01): 97. DOI: https://doi.org/10.1017/s0043933909000 008. 